\title{
Robert GROCHOWSKI
}

Collegium Europaeum Gnesnense

Uniwersytet im. Adama Mickiewicza, Poznań

\section{Demokracja a państwo prawa}

Termin państwo prawa (Rechtsstaat) lepiej odzwierciedla to zagadnietucji RP). W krajach demokratycznych zasada rządów prawa opiera się na spełnieniu przez ustrój polityczno-prawny i system społeczny państwa, między innymi następujących warunków: na poziomie politycznym - zasady dotyczą większości praw obywateli do wyboru ustroju politycznego, przy zagwarantowaniu prawnej i faktycznej możliwości istnienia legalnej i zorganizowanej opozycji oraz pokojowej wymiany ekip rządzących; na poziomie społecznym - podstawowe prawa obywateli i ich wolności stanowią podstawę ustroju społecznego; na poziomie ekonomicznym - własność prywatna i wolny rynek są podstawą systemu ekonomicznego ${ }^{1}$. Prawa i wolności obywatelskie są pomocne w oddzieleniu sfery publicznej, w którą państwo może inwestować, od sfery prywatnej, w którą inwestowanie przez państwo jest zakazane. Własność prywatna i wolny rynek dają możliwość funkcjonowania organizacjom i stowarzyszeniom obywatelskim, które dzięki temu mogą uzyskać niezależność prawną i faktyczną od państwa, co stanowi gwarancję istnienia państwa prawa i obywatelskiego społeczeństwa ${ }^{2}$.

Demokracja natomiast już w swoim słowotwórczym znaczeniu jest władztwem ludu. W państwie demokratycznym ciałem władczym jest lud. Lud jednak jako zbiorowość nie jest zdolny do wykonywania żadnej funkcji państwowej poza wyborami - nie jest zdolny do sprawowania rządów, a więc nie jest władcą bezpośrednim. Władca bezpośredni, jako ciało

1 Przeciwieństwem społeczeństwa obywatelskiego, które jest warunkiem istnienia państwa prawa, jest społeczeństwo upaństwowione, czyli zespół organizacji i instytucji, które są podporządkowane państwu i które państwo wykorzystuje, w celu kontrolowania społeczeństwa i realizowania swoich interesów poprzez społeczeństwo. L. Morawski, Główne problemy współczesnej filozofii prawa. Prawo w toku przemian, Warszawa 2005, s. 324.

2 J. A. Hall, Civil Society, Cambridge 1995, s. 81. 
wybrane jest jednostką zwierzchnia, naczelną i bardzo często sprawia wrażenie, że nie jest przed nikim odpowiedzialny, a swoje decyzje każe uznawać za wolę ludu ${ }^{3}$. Biorąc za podstawę inny punk widzenia, demokrację możemy również uznać, jako pewnego rodzaju reżim demokratyczny. Reżim taki to sytuacja, w której społeczeństwo ma szeroki wpływ na działalność aparatu państwowego, a aparat cieszy się poparciem większości społeczeństwa i jest wyłaniany w znacznym stopniu przez demokratyczne mechanizmy wyborcze. Taka demokracja oznacza również, że działalność państwa jest zgodna z prawem szanującym podstawowe uprawnienia i wolności obywatelskie ${ }^{4}$.

Powyższe dwa pojęcia łączy w sobie Konstytucja, zwana również ustawą zasadniczą. Słowo to pochodzi z języka łacińskiego constituere i oznacza ustanawianie, urządzanie, uporządkowanie oraz nadawanie określonej formy. Termin konstytucja nie zawsze w języku polskim odnosił się do aktu prawnego. W dawniejszej Polsce używano słowa konstytucja także na określenie budowy czyjegoś ciała ${ }^{5}$ W obecnych czasach konstytucja to jednak przede wszystkim akt prawny o najwyższej mocy, regulujący najbardziej podstawowe zagadnienia ustroju politycznego, społecznego i gospodarczego danego państwa. O tak rozumianej konstytucji można mówić dopiero od końca wieku XVIII, czyli epoki oświecenia. Czasy te zaowocowały postulatem równości ludzi wobec prawa oraz wprowadzeniem tych postulatów do pierwszych aktów prawnych rewolucji amerykańskiej i rewolucji francuskiej ${ }^{6}$. Nie oznacza to, że wcześniej nie istniały akty prawne, które pełniły rolę podstaw pod system ustrojowy

3 Cz. Znamierowski, Szkoła prawa. Rozważania o państwie, Warszawa 1999, s. $375-378$.

${ }^{4}$ Przeciwieństwami takiego reżimu są: reżim autokratyczny i reżim totalitarny. W pierwszym przypadku działalność państwa wobec społeczeństwa nie jest związana z prawem, nie podlega kontroli ze strony społeczeństwa - częste stosowanie środków przymusu. Drugi rodzaj zmierza natomiast do poddania swojej kontroli wszystkiego co napotka, czyli zarówno państwa, jak i społeczeństwa. Narzuca obywatelom własny system wartości i wzorców postępowania. J. Wawrzyniak, Zarys polskiego ustroju konstytucyjnego, Bydgoszcz 1999, s. 19.

5 W. Doroszewski, Stownik języka polskiego, t. III, Warszawa 1964, s. 944.

${ }^{6}$ Za pierwszą konstytucję na świecie uważana jest konstytucja Stanów Zjednoczonych Ameryki, powstała 17 wrześnie 1787 r. Obowiązuje ona do dnia dzisiejszego, choć wprowadzono do niej wiele poprawek. Drugą na świecie, a pierwszą w Europie była polska Konstytucja 3 maja z 1791 r. nie odegrała ona większej roli na forum europejskim, ale położyła podwaliny pod polski konstytucjonalizm. J. Wawrzyniak, Zarys polskiego, op. cit., s. 21. 
danych państw. Już w starożytności można było spotkać bardzo ważne ustrojowe akty prawne (Grecja). Także w średniowieczu istniały akty prawne zajmujące szczególną rolę w systemie prawa, np. angielska Magna Charta Libertatum z 1215 r., tzw. Złota Bulla węgierskiego króla Andrzeja II z 1222 r. oraz powstały w Polsce w 1374 r. przywilej koszycki. Nie były to jednak konstytucje, które regulowały system ustrojowy poszczególnych państw - były przede wszystkim umowami między panującymi, a określonym stanem. Wiąże się z tym podział konstytucji na konstytucje w znaczeniu faktycznym i konstytucje w znaczeniu prawnym. Znaczenie faktyczne to nic innego jak istniejący ustrój państwa, niezależnie od tego jakim aktem został określony. Konstytucja w znaczeniu prawnym istnieje wówczas, gdy mamy do czynienia z aktem prawnym pisanym, który reguluje kwestie ustrojowe danego państwa. Konstytucja w znaczeniu prawnym może występować w dwóch postaciach: w znaczeniu formalnym i znaczeniu materialno-prawnym. Obecnie najczęściej spotyka się znaczenie formalne, w którym Konstytucja jest jednym, pisanym aktem prawnym określanym jako „konstytucja” lub „ustawa zasadnicza”. Konstytucja w formie materialno-prawnej to szereg aktów prawnych, które regulują określone fragmenty systemu ustrojowego. Sięgając do historii Polski, z taką sytuacją mieliśmy do czynienia w latach 1992-1997, gdy nasz system ustrojowy regulowany był przez trzy ustawy konstytucyjne. Były to: Mała Konstytucja z 17 października 1992 r., utrzymane w mocy przepisy Konstytucji z 1952 r. oraz ustawa konstytucyjna z 23 kwietnia 1992 r. o trybie przygotowania i uchwalenia Konstytucji Rzeczpospolitej Polskiej. Wówczas nie istniał jeden akt prawny zwany Konstytucją ${ }^{7}$.

Istotnym w świetle naszego państwa jest podział konstytucji dokonany przez Ferdinanda Lassalle. Rozróżnił on ustawy zasadnicze rzeczywiste i ustawy zasadnicze pisane. Za konstytucję rzeczywistą uważa się ustawę zasadniczą, która odzwierciedla aktualny, rzeczywisty układ sił społecznych w państwie. Taka konstytucja ma szanse odegrać ważną rolę i być konstytucją przestrzeganą i respektowaną. Natomiast ustawa zasadnicza pisana jest jedynie zwojem papieru i nie ma żadnego odniesienia do rzeczywistych procesów zachodzących w państwie ${ }^{8}$.

Dla dobra wspólnego zgodnie z Konstytucją ważne są: niepodległość, suwerenność, rządy prawa oraz szanowanie godności człowieka. Do tych

7 Ibidem, rozdz. 1.

8 Patrz F. Lassalle, O istocie konstytucji, Warszawa 1960. 
elementów zaliczyć należy również bezpieczeństwo wewnętrzne i zewnętrzne, rozwój gospodarczy, dziedzictwo narodowe oraz wolność społeczeństwa i jednostek. Zdaniem byłego prezydenta RP, „,w demokratycznym państwie nikt nie ma monopolu na określenie precyzyjnego sensu owych wartości i norm - a przez to znaczenia dobra wspólnego". Podstawowym celem wspólnoty politycznej jest doskonalenie tych mechanizmów wolności, które konkretnych interpretacji nabywały dopiero w procesie orzecznictwa Trybunału Konstytucyjnego9.

Rozpatrując kwestie związane z konstytucją, demokracją i państwem prawa należy się zastanowić, czy koncepcje i pojęcia, do których odwołują się nowe konstytucje, powstałe po upadku starego porządku, posiadają właściwości pozwalające na konsolidację nowych demokracji? W celu lepszego zrozumienia tych zagadnień należy w przypadku Polski odwołać się do stalinowskich konstytucji Europy Środkowo-Wschodniej po 1945 r. Proklamowanie konstytucji tego typu polegało na podporządkowaniu ludowych demokracji, porządkowi ukształtowanemu w ZSRR. Porządek ten opierał się na terrorze wewnętrznym i groźbie militarnej inwazji (Berlin 1953, Węgry 1956, Czechosłowacja 1968). Jedną z najważniejszych zasad owych konstytucji była zasada wiodącej roli proletariatu, jako społecznej reprezentacji systemu i wprowadzenie nowego porządku, np. zniszczenie klas posiadających. We wszystkich państwach demokracji ludowej wyrażano powyższe zasady. Demokracje te przybrały następnie formę demokratycznego centralizmu, co stanowiło o podporządkowaniu wszystkich sił politycznych partii komunistycznej, np. w Polsce PZPR. Bazę stalinowskiego konstytucjonalizmu w znaczeniu prawniczym stanowiła koncepcja praworządności socjalistycznej, która była odpowiedzią na społeczne zapotrzebowanie porządku i stabilności w samowoli władzy totalitarnej. Z drugiej strony konstytucje tego typu deklarowały zbiór demokratycznych zasad i norm, praw i wolności obywatelskich - były to jednak papierowe ustawy zasadnicze. Taka forma konstytucjonalizmu usprawiedliwiała swoich funkcjonariuszy i zwykłych obywateli. Spowodowało to, że prawo przestało być definiowane jako środek represji. Konstytucja jako źródło prawa stała się tylko symbolem. Władze demokracji ludowej prowadziły z własnymi obywatelami pewną grę w postaci apeli odnoszących się do narodowych mitów i symboli ${ }^{10}$.

9 Państwo i prawo, Warszawa 2005, s. 7.

10 Społeczeństwo w społeczeństwie, http://www.jezyk-polski.pl/pts, 11.04.2007. 
Po zerwaniu więzi politycznej z ZSRR, zaczęto zasadę państwa prawa, która miała odróżniać nowy porządek od starego łączyć z zasadami demokratycznego państwa prawa. Współczesne konstytucje łączą zasadę państwa prawa z ochroną praw człowieka i ochroną godności osoby ludzkiej. Nie oznacza to jednak, że w pełni mamy do czynienia z demokratyczną wyrocznią prawa. Zarzuty dotyczą przede wszystkim niektórych sędziów, którzy w swych działaniach opierają się tylko i wyłącznie na literze prawa, ograniczając tym proces jego interpretacji do wykładni językowej. Zauważyć należy, że sądy konstytucyjne i trybunały ograniczone są przez prawo obowiązujące, które w większości odziedziczone jest z poprzedniego systemu. Instytucje te muszą również stawiać czoła wyzwaniom głębokich przemian oraz czysto instrumentalnemu podejściu do prawa demokratycznie wybranych prawodawców, którzy wprowadzają chaos.

W III Rzeczpospolitej pojawiły się tendencje do regulowania wszystkiego, co spotkać można na drodze do demokracji, za pomocą stale ustanawianych nowych aktów prawnych - na potrzeby chwili, które z kolei stale są zmieniane i nowelizowane. Należy stanowczo stwierdzić, że nowe demokratyczne władze naszego państwa, podobnie jak i stare, niedemokratyczne, traktują prawo przede wszystkim instrumentalnie, uważając, że zależne jest ono od woli stale pojawiających się nowych polityków i ich partii. Z tego to powodu prawo, na którym opiera się konstytucyjna zasada państwa prawa posiada bardzo małą siłę na konsolidację systemu demokracji. Prowadzi to z kolei do składania wielu skarg, które kierowane są do ponadnarodowych instytucji sądowych ${ }^{11}$.

Działanie naszych polityków stoi w sprzeczności z konstytucyjną demokracją. Zasada pierwszeństwa konstytucji stanowi, że konstytucyjne normy adresowane do ustawodawcy mają charakter wiążący. Powszechnie przyjmuje się, że ustawodawca powinien działać w granicach konstytucji, a swoboda jego działań wyznaczona jest przez granice zawarte w normach konstytucyjnych. Swoboda ustawodawcy stanowi poważny problem nawet dla Trybunału Konstytucyjnego, który przy jej rozpatrywaniu powinien brać pod uwagę zasady ustrojowe Konstytucji. Należy przede wszystkim oprzeć się na roli Konstytucji w realizacji zasad demokracji, które gwarantują równość szans i ochronę praw. Bardzo często konflikt taki powstaje poprzez brak politycznego kompromisu ${ }^{12}$. Stając po

${ }^{11}$ Ibidem.

${ }_{12}$ Zasada pierwszeństwa konstytucji w tworzeniu prawa, http://www.konstytucje.pl/pub, 11.04.2007. 
stronie Trybunału Konstytucyjnego należy stwierdzić, że w początkowym okresie był on gwarantem przede wszystkim zgodności norm, przeradzając się z biegiem czasu w gwaranta wartości konstytucyjnych. Już w roku 1928 profesor Wacław Komarnicki stwierdził, że przed majestatem prawa konstytucyjnego schylić musi głowę parlament, Trybunał Konstytucyjny winien zapobiegać wydawaniu ustaw sprzecznych z Konstytucją $^{13}$. Dodać należy, że pierwszeństwo konstytucji znalazło swą podstawę w art. 8, 87 i 188 Konstytucji. Można powiedzieć, że na podłożu normatywnym od 31 grudnia 1989 r., czyli od czasu nowelizacji Konstytucji z 1952 r. Polska jest demokratycznym państwem prawa, które urzeczywistnia zasady sprawiedliwości społecznej ${ }^{14}$. W obecnej Konstytucji z 1997 r. w art. 2 powtórzono tę podstawową normę ustrojową, zgodnie z którą jesteśmy państwem prawa. Konstytucja z 1997 r. stała się dla Polski drogowskazem, który miał nas skierować na drogę koniecznych przemian. Zasada demokratycznego państwa prawa, zapisana w Konstytucji była o tyle ważna, chociaż czasami stanowiła i stanowi tylko zasadę pisaną, że bez jej istnienia Trybunał Konstytucyjny nie mógłby przysłużyć się transformacji polskiego porządku konstytucyjnego. Takie odniesienie zakłada, że interpretacja zasady demokratycznego państwa prawa oraz jej treść ulega ciągłym przemianom. Konstytucja z 1997 r. przyjęła wzorce odpowiadające państwom prawa o bardzo mocno ukształtowanej demokracji $^{15}$. Należy postawić pytanie, czy takie działanie było korzystne dla Polski i społeczeństwa. Czy nie powinniśmy stworzyć własnych podstaw demokracji, które odnosiłyby się do naszej rzeczywistości społeczno-politycznej.

Inaczej spojrzeć trzeba na demokratyczne państwo prawa z punktu widzenia empirycznego. Pewne wątpliwości dotyczą polskiej legislacji, administracji i polskiego sądownictwa, które to instytucje nie odpowiadają konstytucyjnym wzorcom państwa prawa. Wiele wątpliwości związanych z zapisanym w Konstytucji standardem państwa prawa powstaje przy tworzeniu porządku prawnego przez polskiego prawodawcę, wydawaniu decyzji przez urzędy oraz orzeczeń wydawanych przez sądy. Bardzo widoczne w Konstytucji są braki dotyczące pełnego zabezpieczenia prze-

13 List od Prezydenta RP z okazji Zgromadzenia Ogólnego Sędziów Trybunału konstytucyjnego, http://www.prezydent.pl/x.print, 11.04.2007.

14 Art. 1 wprowadzony ustawą z 29 grudnia 1989 r. o zmianie Konstytucji PRL, Dz. U. Nr 75, poz. 444.

${ }^{15}$ Czy Polska jest państwem prawa?, File://C:|Documents\%/20and, 12.04.2007. 
strzegania wolności i praw człowiek oraz obywatela, które mogłyby powyższe wątpliwości zlikwidować.

Terminem państwo prawa określa się państwo rządzone w sposób demokratyczny. Oznacza to, że każdy dorosły obywatel ma równe prawa, dostęp do urzędów oraz możliwość wpływania poprzez uczciwe wybory na skład najwyższych organów państwa, a w państwie takim obowiązują procedury demokratyczne. Zgodnie z Konstytucją takie demokratyczne państwo ma również być państwem prawa, co oznacza, że władza publiczna może działać tylko na podstawie prawa i w jego granicach. W państwie takim obywatel nie może być narażony na żadne ujemne konsekwencje jeśli nie postapił wbrew prawu. Aby nasza ojczyzna - Polska była demokratycznym państwem prawa, władza publiczna nie powinna posiadać wolnego obszaru prawnego działania, a obywatel powinien mieć prawo do: jednoznacznej i stabilnej legislacji, nie zmieniającej się wraz ze zmianą partii rządzącej; opartych na takiej legislacji decyzjach administracji rządowej oraz samorządowej, która traktuje obywateli podmiotowo z poszanowaniem zasad równości oraz do sprawnie funkcjonującego i niezależnego sądu, w którym sprawy rozpatrywane są przez niezawisłych sędziów ${ }^{16}$.

W ostatnich czasach ponad konstytucyjne normy prawne stawia się realizację celów politycznych. Przykładem może być ustawa medialna, która w swoich zasadniczych punktach uznana została przez Trybunał Konstytucyjny za niezgodną z Konstytucją. Ustawa medialna w obecnym brzmieniu jest bardziej polityczna niż demokratyczno-prawna. Również powołanie przez Sejm komisji śledczych różnego typu jest dowodem, że w naszym państwie polityka nie musi być podporządkowana prawu. Stanowczo należy stwierdzić, że w takich przypadkach sam rząd RP odrzuca art. 7 Konstytucji, czyli zasadę legalizmu, rezygnując tym samym z zasady demokratycznego państwa prawa.

Cały czas pogłębia się niewypełnianie przez organy administracyjne swoich obowiązków, co doprowadza do zjawiska bezczynności, a obywatel w takich sytuacjach czuje się bezradny. Do takiego stanu rzeczy przyczynił się zapewne zły stan polskiego prawa, powodując bezkarność urzędników. Podobna sytuacja dotyczy także polityków. Często słyszy się o braku podstaw do odpowiedzialności polityka, powołując się na zasadę domniemania niewinności, przeoczając fakt, że zasada ta ma znaczenie

16 Ibidem. 
jedynie w postępowaniu karnym, a nie odnosi się do podstaw odpowiedzialności politycznej. Poza tym zapomniano już o postępowaniu dyscyplinarnym, które jeżeli w ogóle się pojawia, to trwa bardzo długo, po czym sprawa ulega przedawnieniu. Jednocześnie degradacji uległo przestrzeganie norm prawnych w szerokim tego słowa znaczeniu oraz norm etycznych. Przykładem bezkarności ludzi sprawujących nad nami władzę, którzy wykorzystują prawo dla własnych celów jest sprawa pobicia przez policję chłopaka, który pił alkohol pod sklepem. Trybunał w Strasburgu uznał, że Polska naruszyła artykuł Konwencji Praw Człowieka zakazujący nieludzkiego i poniżającego traktowania. Należy zaznaczyć, że w szpitalu stwierdzono u poszkodowanego złamanie nosa, pęknięcie oczodołu, żuchwy i złamanie ręki. Poszkodowany wniósł oskarżenie przeciwko jednemu z policjantów, ale prokurator rejonowy umorzył postępowanie, dając wiarę wyjaśnieniom policji. Poszkodowany odwołał się od decyzji sądu, ale bezskutecznie - została ona utrzymana. Następnie po kolejnym wniesieniu odwołania, Sąd Okręgowy uchylił wyrok, przekazując sprawę do ponownego rozpatrzenia przez Sąd Rejonowy, który wyrok podtrzymał. Odwołując się z kolei do Trybunału w Strasburgu, organ ten uznał jednoznacznie, że obrażenia powstały w wyniku bicia przez policję. Trybunał stwierdził, że siła użyta przez policję była nieproporcjonalna do okoliczności, co stanowiło naruszenie art. 3 Europejskiej Konwencji Praw Człowieka i Podstawowych Wolności. Ponadto Trybunał stwierdził, że śledztwo przeciwko policjantowi było prowadzone powierzchownie i pozbawione obiektywizmu ${ }^{17}$.

Do niedemokratycznych poczynań naszego rządu zaliczyć należy również szerzącą się na każdym kroku korupcję, która tkwi w systemie funkcjonowania państwa. Duże znaczenie w walce z korupcją mogłaby odegrać wynikająca z art. 61 Konstytucji i z ustawy z 6 września 2001 r. o dostępie do informacji publicznej ${ }^{18}$ jawność, dotycząca zasady życia publicznego. Jawność postępowania może przyczynić się do opanowania korupcji bardziej, niż powoływanie służb do jej wykrywania ${ }^{19}$. Najwięcej

17 Polska winna nieludzkiego traktowania, http://wiadomosci.gazeta.pl/wiadomosci, 12.04.2007.

18 Dz. U. Nr 112, poz. 1198.

19 Organy administracji publicznej są zobowiązane do działania w granicach prawa, które wyznacza art. 6 Konstytucji. Zbierając dane osobowe o obywatelach powinny legitymować się stosowną podstawą prawną zgodnie z art. 51 ust. 1 i 2 Konstytucji, co przesądza o tym, że wszystkie zbiory danych osobowych, prowadzone przez admi- 
niepokojów budzą jednak wypowiedzi polityków, podważające zasadę niezależności sądów i niezawisłości sędziego oraz odnoszące się do całego pojęcia wymiaru sprawiedliwości. Przykładem takiego braku szacunku do polskiej demokracji i wynikającego z niej poszanowania prawa jest wypowiedź wicepremiera A. Leppera, który powiedział, zapytany, czy stawi się na rozprawie: „,.. dajcie mi spokój, co to za sąd"20.

Przyznać trzeba, że państwo nie ułatwia swoim obywatelom dostępu do wymiaru sprawiedliwości. Dostępność do sądów jest utrudniona przez wysokie koszty postępowania, a zwolnienie z kosztów ma charakter arbitralny ${ }^{21}$. Polscy obywatele mają trudności w korzystaniu z pomocy prawnej, która gwarantuje nam Konstytucja. Przewlekłość postępowania, wyznaczanie wielu terminów rozpraw, stawia pod znakiem zapytania, zasadę koncentracji materiału dowodowego. Na działaniu wymiaru sprawiedliwości, polegającym na zapewnieniu bezpieczeństwa obywateli opiera się również demokratyczne państwo prawa. Zbyt często instytucje te kierują się względami politycznymi, a przecież żaden z sędziów czy prokuratorów nie może być urzędnikiem politycznym - jest to wbrew społecznej demokracji ${ }^{22}$.

Należy stwierdzić, że brakuje nam jeszcze bardzo dużo do stania się demokratycznym państwem prawa, a poziom przestrzegania przez władze publiczne demokratycznej zasady państwa prawa znacznie się obniżył. Przykładem może być wolność mediów. Stosowana coraz częściej cenzura jest przykładem wywierania wpływu na media przez partie rządzące. Nie na tym powinno opierać się demokratyczne państwo prawa, które wymaga wolności mediów i pluralizmu politycznego, wolności słowa powiązanej z odpowiedzialnością za nie. Ciągłe podglądanie i podsłuchiwanie polskich obywateli jest zabiegiem wziętym z dawnego ustroju socjalistycznego naszego państwa i nijak ma się do demokracji ${ }^{23}$. Szokujące są również metody zmian wizerunku Polski, przeprowadzane przez Ligę

nistrację publiczną powinny być prowadzone zgodnie z prawem. Podstawą udostępnienia danych osobowych na rzecz podmiotów z sektora publicznego może być tylko i wyłącznie przepis prawa. Państwo i prawo, Warszawa 2006, s. 44 i 47.

20 Wydarzenia - Polsat, godz. 11.40, 14.04.2007.

21 Arbitralny to nie liczący się z nikim i niczym; bezwzględny; narzucający bez uzasadnienia swoją myśl, swoją wolę; będący samowolnym. F. Jakubowski, Maty stownik wyrazów obcych, Warszawa 1959, s. 34.

${ }^{22}$ Czy Polska jest państwem prawa, file://C:Idocuments\%20, 12.04.2007.

23 Wiadomości - TVP I, skrót transmisji z posiedzenia plenarnego PSL, wypowiedź W. Pawlaka, godz. 19.35, 15.04.2007. 
Polskich Rodzin. Partia ta jest głęboko homofobiczną organizacją, a minister R. Giertych swymi nowymi przepisami próbuje walczyć ze wszystkim i wszystkimi, wygłaszając twierdzące mowy o homoseksualizmie w szkołach i niskim poziomie na uniwersytetach. Bruksela już teraz ostrzega, że takie działania idą w kierunku nieprzestrzegania praw człowieka do wolności. Ostrzeżenie R. Giertycha przed integracją społeczności muzułmańskich z Europą jest całkowicie sprzeczne z art. 32 ust. 2, art. 35, art. 53 i art. 56 Konstytucji. Propozycje populistów nie tylko szokują Brukselę, ale również spowodowały duży spadek popularności polskiego rządu. Należy stwierdzić, że wszystkie takie posunięcia aparatu władzy szkodzą wizerunkowi naszego kraju i nie propagują demokratycznych zasad równości i zrozumienia ${ }^{24}$. Polska nie jest jednak odosobnionym krajem unijnym, w którym zapisy konstytucyjne dotyczące demokratycznego państwa prawa nie sprawdzają się. Podobna sytuacja ma miejsce w innych Państwach Członkowskich. Liczne organizacje nawołują do zmiany tego stanu rzeczy. Przykładem jest „dziesięć zasad Attac ${ }^{25} \mathrm{dla}$ demokratycznej i socjalnej konstytucji”. Stowarzyszenie to stwierdza, że aktualny kształt Unii Europejskiej jest poważną przeszkodą w pogłębianiu demokracji, zachowaniu fundamentalnych praw oraz sprawiedliwości społecznej. Brak demokracji w tym przypadku jest skutkiem rządzenia poprzez zespół traktatów, które narzucają gospodarkę neoliberalną $^{26}$ dla Państw Członkowskich i całego świata. Stwierdzono, że nowy traktat powinien być zbudowany na najlepszych wzorcach demokratycznych, a podstawowymi zasadami nowego traktatu powinny być: godność człowieka, prawo, demokracja reprezentatywna i uczestnicząca, bezpieczeństwo socjalne i zapobieganie wykluczeniu, solidarność, równość kobiet i mężczyzn, wsparcie i zaangażowanie dla pokoju. Stwierdzono jednocześnie, że nowy traktat powinien oferować zrozumiałe wzory demokracji bezpośredniej ${ }^{27}$.

24 Polska szokuje Europe, http://www.polityka.org.pl/index, 13.04.2007.

25 Attac jest alterglobalistyczną organizacją działającą na rzecz demokracji w Europie i poszanowania zasad socjalnych. Jej sygnatariuszami są: Niemcy, Austria, Belgia, Dania, Hiszpania, Finlandia, Francja, Grecja, Węgry, Włochy, Jersey, Norwegia, Holandia, Polska, Szwecja i Szwajcaria. Dziesięć zasad Attac dla demokratycznej i socjalnej konstytucji, http://www.trybuna-robotnicza.pl/index, 11.04.2007.

26 Neoliberalizm gospodarczy dopuszcza ingerencję państwa w określonym zakresie. Słownik wyrazów obcych PWN, Warszawa 2002, s. 763.

27 Ibidem. 
Powyższe przykłady pokazują, że mamy do czynienia z demokracją, która prawdopodobnie chyli się ku upadkowi ${ }^{28}$ nie mogąc nadążyć za globalizacją i powoduje degradację państwa prawa. W takiej sytuacji postawić można tylko jedno pytanie: w czym tkwi ten problem? Czy winę za taki stan rzeczy ponoszą rządy poszczególnych państw, czy może obecne prawo. Bez udzielenia odpowiedzi na to pytanie, trudno jest szukać perspektyw i rozwiązań dla Polski i Europy na demokratyczne państwo prawa.

\section{Summary}

The paper aims to demonstrate the meaning of the notions of democracy and a state of law in relation to the Constitution as the fundamental law. All these issues are related to the contemporary social and political situation of Poland and the European Union. It is observed that in the state of law, civic fredoms and rights are helpful in separating the public from the private. Democracy is the rule of the people who need to be headed by a direct ruler. The notions of the 'state of law' and 'democracy' become mutually related to the Constution, referred to as the fundamental law. The paper shows the contemporary status of democracy, compared to the state of law, and it provokes the question whether we should lay our own foundations of democracy which wouldspond to our social and political reality.

28 Jak stwierdził prof. T. Nałęcz, ,demokracja chyli się ku upadkowi, co nie oznacza, że jej wcale nie ma". Warto rozmawiać (powtórka audycji z PR I TVP), TVP Polonia, 26.05.2007. 
